\title{
PENGETAHUAN TENTANG COVID-19 BERHUBUNGAN DENGAN KEPATUHAN KELUARGA MEMAKAI MASKER DI IGD RUMAH SAKIT
}

\author{
Naomi Christina Mareta Hutapea*, Nilawati Soputri \\ Fakultas Ilmu Keperawatan, Universitas Advent Indonesia, Jl. Kolonel Masturi No.288, Cihanjuang \\ Rahayu, Kec. Parongpong, Kabupaten Bandung Barat, Jawa Barat 40559, Indonesia \\ *naomifathur72@gmail.com (+6285299911751)
}

\begin{abstract}
ABSTRAK
Pengunjung yang datang di Instalasi Gawat Darurat Rumah Sakit masih banyak yang tidak menggunakan masker atau menggunakan masker tetapi tidak benar. Penelitian bertujuan untuk mendapatkan hubungan pengetahuan tentang COVID-19 dengan kepatuhan memakai masker di IGD. Pengambilan sampel dilakukan dengan menggunakn teknik accidental sampling dengan jumlah 70 orang. Instrumen yang digunakan adalah kuesioner tentang COVID-19 dan lembar observasi kepatuhan memakai masker. Data dianalisis secara univariat menggunakan mean dan bivariat menggunakan pearson product moment correlation. Hasilnya didapati nilai $\mathrm{p} 0,000$ $(\mathrm{p}<0,05)$. Hasilnya yaitu didapati hubungan yang signifikan antara pengetahuan tentang COVID-19 dengan kepatuhan memakai masker.
\end{abstract}

Kata kunci: covid-19; kepatuhan menggunakan masker; pengetahuan

\section{KNOWLEDGE ABOUT COVID-19 RELATED TO FAMILY COMPLIANCE OF WEARING MASKS IN EMERGENCY ROOM OF HOSPITAL}

\begin{abstract}
The visitors who come to the Emergency Room don't wear masks or not well of using masks. The aim of the study was to obtain the relationship between knowledge about COVID-19 and adherence to wearing masks in the Emergency Room of Bandar Lampung Adventist Hospital. Sampling was done using accidental sampling technique with total 70 people. The instruments used are questionnaires about COVID-19 and observation sheets for wearing masks. Data were analyzed univariately using mean and bivariately using Pearson product moment correlation. The result is $p 0,000(p<0,05)$. There is a significant relationship between knowledge about COVID-19 and adherence to wearing masks.
\end{abstract}

Keywords: covid-19, compliance using masks, knowledge

\section{PENDAHULUAN}

Corona Virus-19 (COVID-19) merupakan salah satu virus yang menyerang sistem pernapasan manusia. Virus ini telah menjadi pandemi karena telah menyerang seluruh dunia termasuk Indonesia. COVID-19 dapat menimbulkan gejala ringan hingga berat. Gejala ringan yang biasanya dirasakan oleh penderita COVID-19 adalah demam, batuk ringan, sakit kepala, anosmia, pilek dan bersin, laju pernapasan sebanyak 12-20 kali per menit. Gejala COVID-19 kategori sedang seperti demam, batuk dan pilek, anoreksia, anosmia, nyeri pada tulang, nyeri di tenggorokan, frekuensi pernapasan 20 hingga 30 kali per menit, sesak napas yang tidak disertai dengan distress pernapasan. Gejala berat menimbulkan demam, batuk, anoreksia, nyeri tulang dan tenggorokan, diare, frekuensi napas di atas 30 kali per menit 
dan sesak napas yang disertai dengan distress pernapasan (Kemenkes, 2021).

COVID-19 bisa menyebar dengan cepat dan menginfeksi orang yang berada di sekitarnya tanpa pandang usia. Peningkatan jumlah kasus terkonfirmasi COVID-19 terjadi dalam waktu yang sangat cepat. pada akhir April 2021 didapat 5.500 kasus baru, akhir Mei 2021 didapat 5.662 kasus, akhir Juni 2021 meningkat menjadi 21.807 kasus, dan Juli 2021 mencapai 54.000 kasus (Kemenkes, 2021). Peningkatan kasus ini, sangat membutuhkan penanganan segera. Departemen Kesehatan RI (2020) telah menghimbau masyarakat untuk menerapkan sejumlah protokol kesehatan yang harus dilakukan untuk mencegah penularan COVID-19 seperti menggunakan masker dengan tepat, mencuci tangan menggunakan air mengalir dan sabun dan menjaga jarak minimal satu meter, menghindari kerumuman dan mengurangi mobilitas (Sheng, 2020). Usaha untuk memutuskan penyebaran COVID-19 membutuhkan pemahaman yang tepat dan pengetahuan yang sesuai dari semua elemen masyarakat yang ada.

Pengetahuan tentang penyakit COVID19 adalah salah satu hal yang penting untuk diketahui untuk mencegah timbulnya peningkatan jumlah kasus terkonfirmasi COVID-19. Tingkat pengetahuan pasien tentang COVID-19 dapat dijabarkan sebagai hasil dari mengetahui dan memahami penyakit COVID-19 tersebut, cara pencegahannya, pengobatan COVID-19 dan komplikasi yang muncul akibat COVID-19 (Mona, 2020). Sari dan Atiqoh (2020) melakukan penelitian mengenai tingkat pengetahuan masyarakat tentang COVID-19 di desa Ngrongah. Didapati 30,65\% masyarakat memiliki tingkat pengetahuan yang rendah tentang penyakit COVID-19. Hal ini menunjukan masih banyak masyarakat di daerah tersebut yang memiliki tingkat pengetahuan yang tergolong kurang tentang penyakit COVID-19.

Di era pandemi Covid-19, masyarakat diharapkan mematuhi protokol kesehatan. Salah satu hal dari protokol kesehatan yang harus dipatuhi adalah pemakaian masker sesuai prosedur kesehatan. Menurut Adisasmito (2020), kepatuhan masyarakat dalam melaksanakan salah satu protokol kesehatan memakai masker di Indonesia masih kurang, dimana 59,32\% masyarakat tidak patuh memakai masker. Hal ini menyebabkan kemungkinan penyebaran penyakit Covid-19 meningkat.

Menurut Kemenkes (2021) dari 34 provinsi di Indonesia, hanya 6 provinsi yang memiliki tingkat kepatuhan menggunakan masker lebih dari $85 \%$ yaitu Provinsi Bali, Daerah Istimewa Yogyakarta, Jawa Timur, Kalimantan Tengah, Kalimantan Utara dan Sulawesi Utara. Selebihnya tingkat kepatuhan menggunakan masker masih rendah. Hal ini dapat diartikan bahwa masyarakat provinsi Lampung merupakan masyarakat yang tergolong kurang patuh dalam memakai masker.

Berdasarkan pengamatan awal penulis ditemukan banyak masyarakat tidak sadar akan bahaya COVID-19 dan banyak diantaranya melalaikan pemakaian masker. Peneliti mengamati bahwa dari 11 orang pengunjung yang datang ke IGD RSABL, pada tanggal 7 Juni 2021 didapati 5 orang tidak memakai masker dan 6 orang lainnya memakai masker tetapi tidak sesuai standart pemakaian masker seperti menaruh masker di dagu dan melepas 
masker pada saat berbicara dengan orang lain. Tujuan dari penelitian ini yaitu untuk mendapatkan gambaran tentang hubungan antara tingkat pengetahuan keluarga pasien tentang COVID-19 dan tingkat kepatuhan menggunakan masker yang benar di IGD.

\section{METODE}

Penelitian ini merupakan penelitian dengan jenis kuantitatif. Desain penelitian yang digunakan adalah deskriptif korelasi. Populasi yang diteliti yaitu keluarga pasien yang mendampingi pasien berobat ke IGD. Sampel berjumlah 70 orang yang dipilih dengan cara menggunakan teknik pengambilan sampel accidental sampling, yaitu keluarga pasien yang datang ke IGD RSABL pada pagi hari dari tanggal 20 - 27 Juni 2021 dari jam 07.00 sampai jam 14.00 dan secara sukarela mau berpartisipasi dalam penelitian. Penelitian ini telah lulus uji etik dari Komite Etik Penelitian Kesehatan Universitas Advent Indonesia dengan nomor No.162/KEPK-FIK.UNAI/EC/VI/21

dan Komite Etik Penelitian Kesehatan RS Advent Bandar Lampung dengan nomor 14/KEPKRSABL/VI/2021. Instrument penelitian yang digunakan adalah kuesioner tingkat pengetahuan mengenai COVID-19 yang diadopsi dari Darmayanti (2020) yang telah dimintai ijin untuk penggunaan kuesioner tersebut. Kuesioner telah diuji dengan nilai Cronbach Alpha 0,770. Untuk mengukur kepatuhan menggunakan masker digunakan lembar observasi penggunaan masker yang benar, dimodifikasi dari panduan penggunaan masker yang benar oleh WHO (2020). Data yang terkumpulkan diolah dengan cara univariat dan bivariat. Data demografi diolah dengan menggunakan perhitungan persentasi, tingkat pengetahuan dan kepatuhan menggunakan masker menggunakan rumus rata-rata, dan hubungan antara pengetahuan tentang COVID-19 dan kepatuhan memakai masker menggunakan rumus pearson product moment correlation.

\section{HASIL}

Distribusi data demografi responden berdasarkan jenis kelamin, usia, pendidikan dan pekerjaan dapat diperhatikan di tabel 1.

Berdasarkan tabel 1, profil demografi responden dalam penelitian ini yaitu $50 \%$ laki-laki dan $50 \%$ perempuan. Usia, 26-44 tahun berjumlah 37,14 \%, 45 - 59 tahun $34,29 \%$ dan berusia $19-$ 25 tahun sebanyak 12,86 \%. Profil pekerjaan responden adalah $30 \%$ bekerja sebagai karyawan swasta, 28,57 $\%$ sebagai wirausaha dan sebanyak $27,14 \%$ sebagai ibu rumah tangga. Pendidikan responden terbanyak adalah SMA $42,86 \%$, S1 21,43 \% dan SD sebanyak $17,14 \%$.

Tabel 2 menunjukkan bahwa sekitar $25,71 \%$ responden mempunyai pengetahuan yang tergolong sangat tinggi mengenai COVID-19, 35,72\% responden mempunyai pengetahuan yang tergolong tinggi, 34,29\% responden mempunyai pengetahuan cukup, dan 4,29\% responden memiliki pengetahuan yang tergolong rendah. Tabel 2 juga menampilkan tingkat kepatuhan keluarga pasien dalam menggunakan masker. 61,43 \% responden tidak patuh dalam menggunakan masker secara tepat. $38,57 \%$ responden menggunakan masker secara tepat. 
Tabel 1.

Distribusi Karakteristik Responden $(\mathrm{n}=140)$

\begin{tabular}{|c|c|c|c|}
\hline Variabel & Kategori & $\mathrm{f}$ & $\%$ \\
\hline \multirow[t]{2}{*}{ Jenis Kelamin } & Laki-laki & 35 & 50 \\
\hline & Perempuan & 35 & 50 \\
\hline \multirow[t]{5}{*}{ Umur } & $13-18$ tahun & 3 & 4,29 \\
\hline & $19-25$ tahun & 9 & 12,86 \\
\hline & $26-44$ tahun & 26 & 37,14 \\
\hline & $45-59$ tahun & 24 & 34,29 \\
\hline & $>60$ tahun & 8 & 11,43 \\
\hline \multirow[t]{7}{*}{ Pekerjaan } & IRT & 19 & 27,14 \\
\hline & Pegawai Swasta & 21 & 30 \\
\hline & ASN & 4 & 5,71 \\
\hline & TNI/Polri & 0 & 0 \\
\hline & Pelajar & 5 & 7,14 \\
\hline & Wirausaha & 20 & 28,57 \\
\hline & Tidak bekerja & 1 & 1,43 \\
\hline \multirow[t]{6}{*}{ Pendidikan } & Tidak sekolah & 3 & 4,29 \\
\hline & SD sederajat & 12 & 17,14 \\
\hline & SMP sederajat & 7 & 10 \\
\hline & SMA sederajat & 30 & 42,86 \\
\hline & S1 & 15 & 21,43 \\
\hline & $\mathrm{S} 2$ & 3 & 4,29 \\
\hline
\end{tabular}

Tabel 2.

Persentase Pengetahuan dan Kepatuhan $(n=140)$

\begin{tabular}{cccc}
\hline Variabel & Kategori & f & $\%$ \\
\hline \multirow{3}{*}{ Tingkat } & Sangat rendah & 0 & 0 \\
\cline { 2 - 4 } Pengetahuan & Rendah & 3 & 4,29 \\
\cline { 2 - 4 } & Cukup & 24 & 34,29 \\
\cline { 2 - 4 } & Tinggi & 25 & 35,72 \\
\cline { 2 - 4 } & Sangat Tinggi & 18 & 25,71 \\
\hline Kepatuhan & Patuh & 27 & 38,57 \\
& Tidak patuh & 43 & 61,43 \\
\hline
\end{tabular}

Tabel 3.

Hubungan Tingkat Pengetahuan dan Kepatuhan $(\mathrm{n}=140)$

\begin{tabular}{clcccc}
\hline $\begin{array}{c}\text { Spearman } \\
\text { Rho }\end{array}$ & \multicolumn{1}{c}{ Variabel } & Mean & Standar Deviasi & Sig & $\begin{array}{c}\text { Correlation } \\
\text { Coeficient }\end{array}$ \\
\cline { 2 - 5 } & $\begin{array}{l}\text { Tingkat } \\
\text { Pengetahuan }\end{array}$ & 7,26 & 1,81 & 0,000 & 0,42 \\
\cline { 2 - 5 } & Kepatuhan & 3,87 & 1,09 & 0,000 & \\
\hline
\end{tabular}


Pada tabel 3 dapat dilihat rata-rata tingkat pengetahuan responden tentang COVID-19 adalah 7,26 dengan standar deviasi 1,81 yang termasuk kedalam kategori tinggi. Rata-rata tingkat kepatuhan keluarga pasien dalam menggunakan masker adalah 3,87 dengan standar deviasi 1,09 termasuk dalam kategori tidak patuh. Terdapat hubungan yang bermakna dari tingkat pengetahuan COVID-19 dan tingkat kepatuhan keluarga pasien dalam memakai masker dengan nilai sig 0,000 $<0,05$ dan keeratan hubungan 0,42.

\section{PEMBAHASAN}

Pada tabel pertama dalam penelitian ini didapati hasil profil demografi responden dalam penelitian ini adalah $50 \%$ laki-laki dan $50 \%$ perempuan. Usia, 26-44 tahun berjumlah 37,14\%, 45 - 59 tahun $34,29 \%$ dan berusia $19-$ 25 tahun sebanyak 12,86\%. Profil pekerjaan responden adalah $30 \%$ bekerja sebagai karyawan swasta, 28,57 $\%$ sebagai wirausaha dan sebanyak $27,14 \%$ sebagai ibu rumah tangga. Pendidikan responden terbanyak adalah SMA $42,86 \%$, S1 21,43 \% dan SD sebanyak $17,14 \%$.

Pada tabel kedua hasil yang didapati dalam penelitian ini yaitu sebagian besar responden memiliki tingkat pengetahuan tinggi dengan nilai ratarata 7,26 . Pengetahuan yang tinggi dari masyarakat diharapkan akan menciptakan kepatuhan yang maksimal. Mujiburahman (2020) mengungkapkan bahwa pengetahuan semakin baik karena daya tangkap seseorang dan pola pikir seseorang akan semakin berkembang dengan semakin bertambahnya usia seseorang. Pengetahuan merupakan salah satu hal yang penting yang harus diperhatikan oleh masyarakat khususnya untuk mencegah penularan virus COVID-19.
Pengetahuan masyarakat sangat berguna dalam menekan penularan virus COVID-19 dikarenakan tingkat pengetahuan dan penilaian yang baik terhadap suatu hal maka akan mempengaruhi seseorang dalam menentukan keputusan untuk melakukan dan menghadapi sesuatu (Purnamasari, 2020).

Hasil penelitian ini juga didapati masih sedikit keluarga pasien yang patuh memakai masker secara tepat dengan nilai rata-rata 3,87 . Hal ini sejalan dengan hasil penelitian yang dilakukan oleh Mushidah (2021) yang mana ditemukan sebanyak 70,4\% responden yang tidak patuh dalam menggunakan masker. Dalam rangka mencegah penularan virus COVID-19 maka WHO (2020) mengeluarkan protokol kesehatan di mana salah satunya adalah penggunaan masker untuk mencegah penularan virus baik dari pemakai maupun kepada orang lain yang berada di sekitar lingkungan penderita. Protokol tersebut juga mendorong agar setiap negara dapat membuat kebijakan yang mengatur mengenai penggunaan masker kepada seluruh warga negaranya untuk menurunkan tingkat penyebab virus COVID-19. Penggunaan masker disarankan untuk digunakan pada ketika seseorang berada di luar rumah, tempat dengan kepadatan yang tinggi, kerumunan di mana tidak bisa menjaga jarak fisik minimal satu meter, berada di ruangan tertutup ataupun berada di tempat yang dianggap banyak orang yang mengidap COVID-19 seperti di rumah sakit ataupun tempat isolasi.

Pada tabel ketiga dalam penelitian ini didapati bahwa ada hubungan yang signifikan antara tingkat pengetahuan keluarga pasien tentang COVID-19 dengan tingkat kepatuhan penggunaan masker dengan tepat dengan tingkat 
keeratan cukup. Hal ini berarti jika pengetahuan mengenai COVID-19 meningkat maka tingkat kepatuhan menggunakan masker akan meningkat. Hal ini sejalan dengan penelitian yang dilaksankan oleh Sari (2020) mengenai hubungan tingkat pengetahuan masyarakat dengan kepatuhan masyarakat dalam menggunakan masker di mana ditemukan hubungan antara kedua variabel tersebut di mana kepatuhan penggunaan masker mempunyai tingkat keefektivitas yang baik dalam hal pencegahan penyebaran virus COVID-19.

Penelitian ini juga sejalan dengan penelitian yang dilaksanakan oleh Mushidah (2021) di mana terdapat hubungan antara tingkat pengetahuan dan sikap tentang COVID-19 terhadap tingkat kepatuhan pemakaian masker, responden yang mempunyai tingkat pengetahuan yang tinggi juga akan memiliki tingkat kepatuhan yang tinggi terhadap penggunaaan masker dan demikian juga dengan hal yang sebaliknya. Masih tingginya jumlah keluarga pasien yang tidak menggunakan masker dengan tepat disebabkan oleh kurang perhatiannya keluarga pasien terhadap pentingkan memakai masker. Hal ini ditandai dengan berbagai alasan keluarga pasien seperti lupa membawa masker, ketinggalan, tidak nyaman dipakai, menganggap bahwa pandemi sudah selesai atau merasa diri sehat dan tidak akan tertular penyakit COVID-19. (Lia, 2020). Masker memiliki tingkat efektivitas yang tinggi yang baik dalam mencegah penularan virus COVID-19 yang menyebar melalui droplet (Ika, 2020).

\section{SIMPULAN}

Penelitian ini menunjukan rata-rata tingkat pengetahuan responden tinggi, dan tingkat kepatuhan keluarga pasien dalam menggunakan masker masih tergolong rendah. Terdapat hubungan yang signifikan antara tingkat pengetahuan keluarga pasien tentang COVID-19 dengan kepatuhan menggunakan masker sebagai upaya pencegahan penyebaran penyakit COVID-19.

\section{DAFTAR PUSTAKA}

Adisasmito, W. (2020). Tingkat Kepatuhan Memakai Masker. (p. https://nasional.kompas.com/read/ 2020/12/04/090258).

Darmayanti, et al. (2020). Gambaran Pengetahuan Masyarakat Tentang COVID-19 Dan Perilaku Masyarakat Di Masa Pandemi COVID-19.

Ika. (2020). Efektifitas Masker Kain Cegah Covid-19. Diakses dari https://doi.org/10.33654/math.v4i $\underline{0.299}$

Kementerian Kesehatan RI. (2021). Peta Sebaran Kasus Covid-19. Diakses dari https://data.covid19.go.id/public/i $\underline{\text { ndex.html }}$

Lia. (2020). Alasan Warga Saat Ditegur Tidak Memakai Masker. Diakses dari

https://www.merdeka.com/jakarta /alasan-warga-saat-ditegur-takpakai-masker-lupa-hinggaanggap-pandemi-sudahselesai.html

Mona, N. (2020). Konsep Isolasi Dalam Jaringan Sosial Untuk Meminimalisasi Efek Contagious (Kasus Penyebaran Virus Corona Di Indonesia). Jurnal Sosial Humaniora Terapan, 2(2).

Mujiburrahman. (2020). Pengetahuan 

Berhubungan
Peningkatan
Pencegahan
Dengan
Perilaku
Covid-19 Di
Masyarakat. Jurnal Keperawatan
Terpadu, 2(2

Mushidah \& Muliawati. (2020). Pengetahuan Dan Sikap Dengan Kepatuhan Penggunaan Masker Sebagai Upaya Pencegahan Penyebaran Covid-19 Pada Pedagang UMKM, 11(1).

Pemerintah Sulawesi Utara. (2020). Marijo Cegah Corona. Diakses dari

https://corona.sulutprov.go.id/

Pundar. (2020). Analisis Faktor-Faktor Yang Mempengaruhi Kepatuhan Perawat Melakukan Hand Hygiene Sesuai SPO Di Ruang Kelimutu Dan Cempaka RSUD Prof. DR. W. Z. Johannes Kupang, 3(2).

Purnamasari, I. \& Anisa, E. R. (2020). No Title. Tingkat Pengetahuan Dan Perilaku Masyarakat Kabupaten Wonosobo Tentang COVID-19, 1(1).

Sari, D. P. \& Atiqoh, N. S. (2020). Hubungan Antara Pengetahuan Masyarakat Dengan Kegunaan Masker Sebagai Pencegahan Covid-19 Di Ngronggah, 1(1).

Sheng, W. H. (2020). Coronavirus Disease 2019 (Covid-19), 1(1).

WHO. (2020). Coronavirus Disease (COVID-19) Situation Report$114 . \quad$ Diakses dari https://www.who.int/docs/defaultsource/coronaviruse/situationreports/20200513-covid-19-sitrep114.pdf?sfvrsn=17ebbbe_4 
Jurnal Penelitian Perawat Profesional, Volume 3 No 3 Hal 453 - 460, Agustus 2021 Global Health Science Group 